\title{
Study of Venturi Scrubber Efficiency For Pesticide Industry
}

\author{
R. Desai, O. P. Sahu* \\ Department of Chemical Engineering, KIT, Jamnagar, Gujarat, India \\ Tel: +919752610958
}

E-mail address: ops0121@gmail.com

\section{ABSTRACT}

A venturi scrubber is designed to effectively use the energy frop the inlet streap to atomize the liquid being used to scrub the gas stream. This type of techn is a part group of air pollution controls. The air pollution generated from the industry s no come se problem for the environment, which affect the living and non living thing the air pollution was found that scrubber shows $99.1 \%$ efficiency.

Keywords: Air pollutant; Dissolved; Health; Suitable; To

\section{INTRODUCTION}

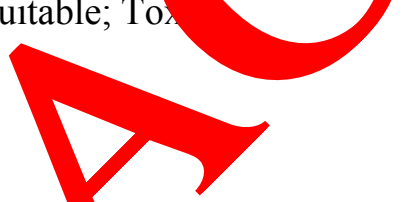

Air pollution is one of ast meartant agents that can affect human health as the environment, plants. anc an is. Inre million deaths from air pollution had been reported annually, mak it one of coven greatest hazards for the world [1]. Humans did not significantly aff it th vironmest until relatively recent times. This is due to human population increa gry for on small part of recorded history, and the bulk of human-made produced air yollution is intim, cly related to industrialization [2]. With rapidly expanding industry, en nore aba ized lifestyles, and an increasing population, concern over the control of man air $\mathrm{p}$ cutants is now clearly a necessity [3]. In all the industry pesticides indust ne of toy c releaser industry and also responsible for environmental pollution.

In ge eral, pro ess emissions can be classified into channelised and fugitive emissions. The nission is a point source emission from process operations and the fugitive emissio an uncontrolled emission from storage tanks/drums, spils, leaks, overflows etc. In order to Aify the various sources of process emissions and their control systems in pesticide industries a questionnaire survey and in-depth study of some pesticide industries were conducted [5-7]. The manufacturing process for a product is a combination of various unit operations and unit process. The material balance of the reactants and products gives the characteristics and quantity of emissions. However, their quantity is constrained by the efficiency of conversion of the system. Chances of pure process emissions of only one gaseous pollutant are very less. The process emissions are contaminated by other vapours of raw materials, solvents and also sometimes product of the unit operations [8]. Theoretical emission of pollutants is difficult to compute. Very often during the unit operations 
wastewater and solid waste are separated, where as waste gas is directly released from the reactions itself. It is observed that no process or production site is directly comparable to another. From the various pesticide manufacturing units, different identified pollutants associated with products are mention in Table 1.

Table 1. Pollutant generated with pesticide manufacturing.

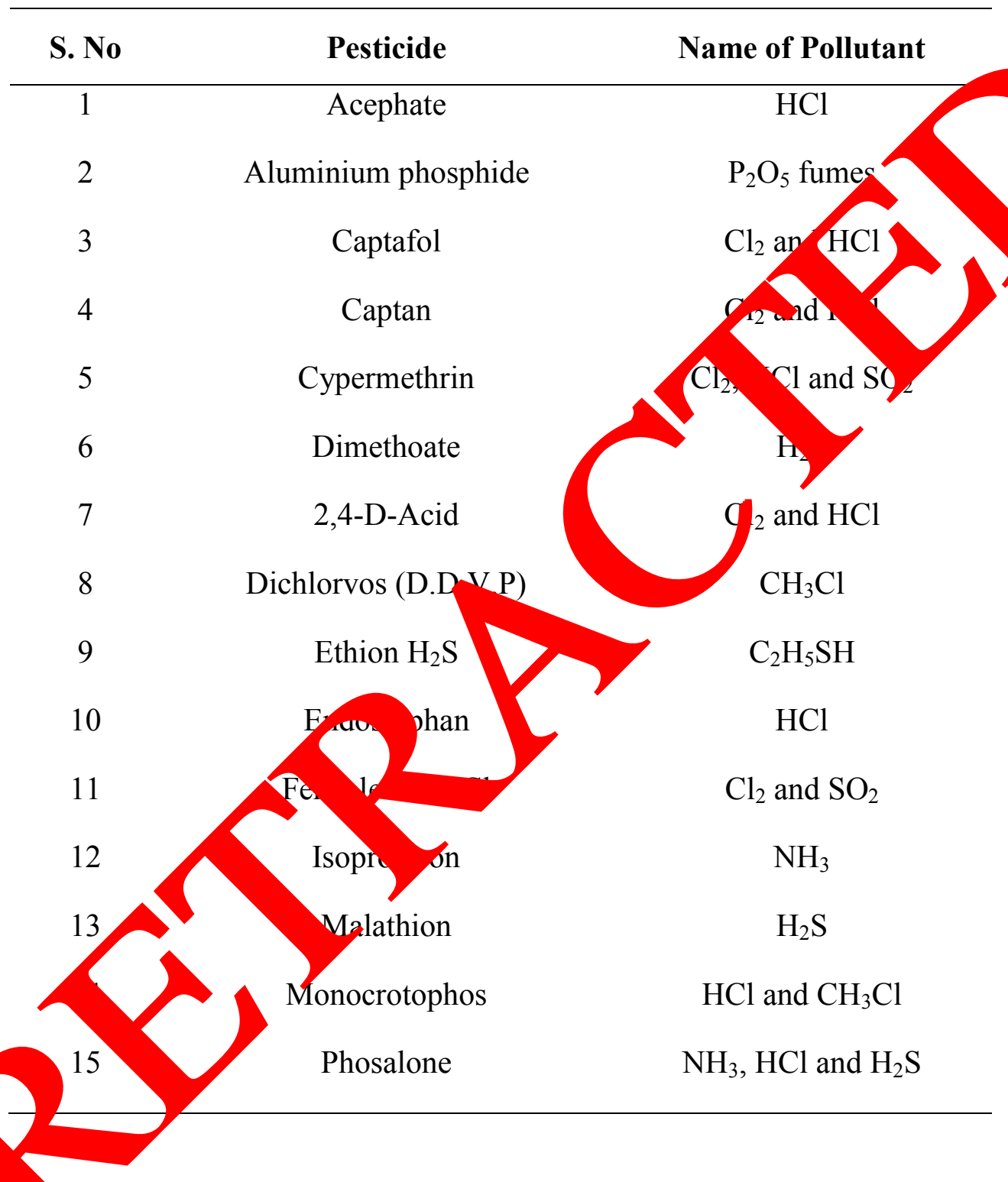

In 1 ure so many method are available for the pollution monitoring for the pesticide industry like, separation techniques, gas solid separation, liquid-liquid separation, gas liquid separation, conversation to harmless end product and thermal destruction. In case of gas solid separation technique cyclone separator, multiclone, electrostatic precipitator, wet dust scrubber and fabric filter including ceramic filter pollution monitoring equipment are used [9]. Among all techniques gas solid separator and the equipment venturi scrubber is the best one. The venturi scrubber is a device which uses liquid in the form of droplets to efficiently remove fine particulate matter from gaseous streams. In the scrubber the gas scrubber accelerates the scrubber liquid, together with the air or gas exhaust stream, to high velocities 
and turbulence. This happens in the bottleneck of the venturi. Behind this bottleneck, the pressure drops, reducing flow velocity back to normal. At this point, contaminant particles are collected and removed [10].

Venturis are the most commonly used scrubber for particle collection and are capable of achieving the highest particle collection efficiency of any wet scrubbing system. As the inlet stream enters the throat, its velocity increases greatly, atomizing and turbulently mixing with any liquid present. The atomized liquid provides an enormous number of tiny droplets for the dust particles to impact on. These liquid droplets incorporating the particles must be removed from the scrubber outlet stream, generally by cyclonic separators [11-13] Darticle removal efficiency increases with increasing pressure drop because of increase turbu. due to high gas velocity in the throat. Venturis can be operated with pressur rops rangi from 12 to $250 \mathrm{~cm}$ (5 to 100 in) of water. Presently pesticide industry ying hanical aided scrubber, it shows very poor efficiency is low. By this study sug, gested usi vent ari scrubber instead of mechanically aided scrubber. The aim of st $\mathrm{Y}$ is calcu the efficiency of venturi scrubber in the monitoring of pollutant generg ad sticide.

\section{MATERIAL AND EXPERIMENTAL METHOD}

\section{1. Material}

The sample was collection from the pesticide dustry. The plant for the manufacture of Agrochemicals is located in nearby Ahmedabad Cit It manufa ture TGP (Technical Grade Pesticides) which include synthetic pyrethroids such a nem sethrin, Permethrin and Alpha Cypermethrin and organic phosphorous unds such as Acephate as well as new Technical Grade Pesticides such as Imi id Triazophos, Formulations and Pesticides Intermediates such as MPB and CM

\section{2. Experimental setup}

A venturi scrubber is ased the process of reducing air pollution in pesticides industry is shown in $\mathrm{F}$ 1. Equip for effectively use the roy from ine inlet gas stream to atomize the liquid being used. Basically it was $r$ of MS, 304, SS316, Polypropylene, PVDF, FRB, and Graphite [14]. The Caustic S da, P tash, wate rime is used as motive fluid used in scrubber [15]. A venturi scrubber ce. ts of mee sections: a converging section, a throat section, and a diverging section. The in gas stre $m$ enters the converging section and, as the area decreases, gas veloc reases ar cordance with the Bernoulli equation). Liquid is introduced either at the roat at the en ance to the converging section.

forced to move at extremely high velocities in the small throat section, shears iquid from its walls, producing an enormous number of very tiny droplets. Particle and gas re val occur in the throat section as the inlet gas stream mixes with the fog of tiny liquid droplets. The inlet stream then exits through the diverging section, where it is forced to slow down. Venturi can be used to collect both particulate and gaseous pollutants, but they are more effective in removing particles than gaseous pollutants [16]. 


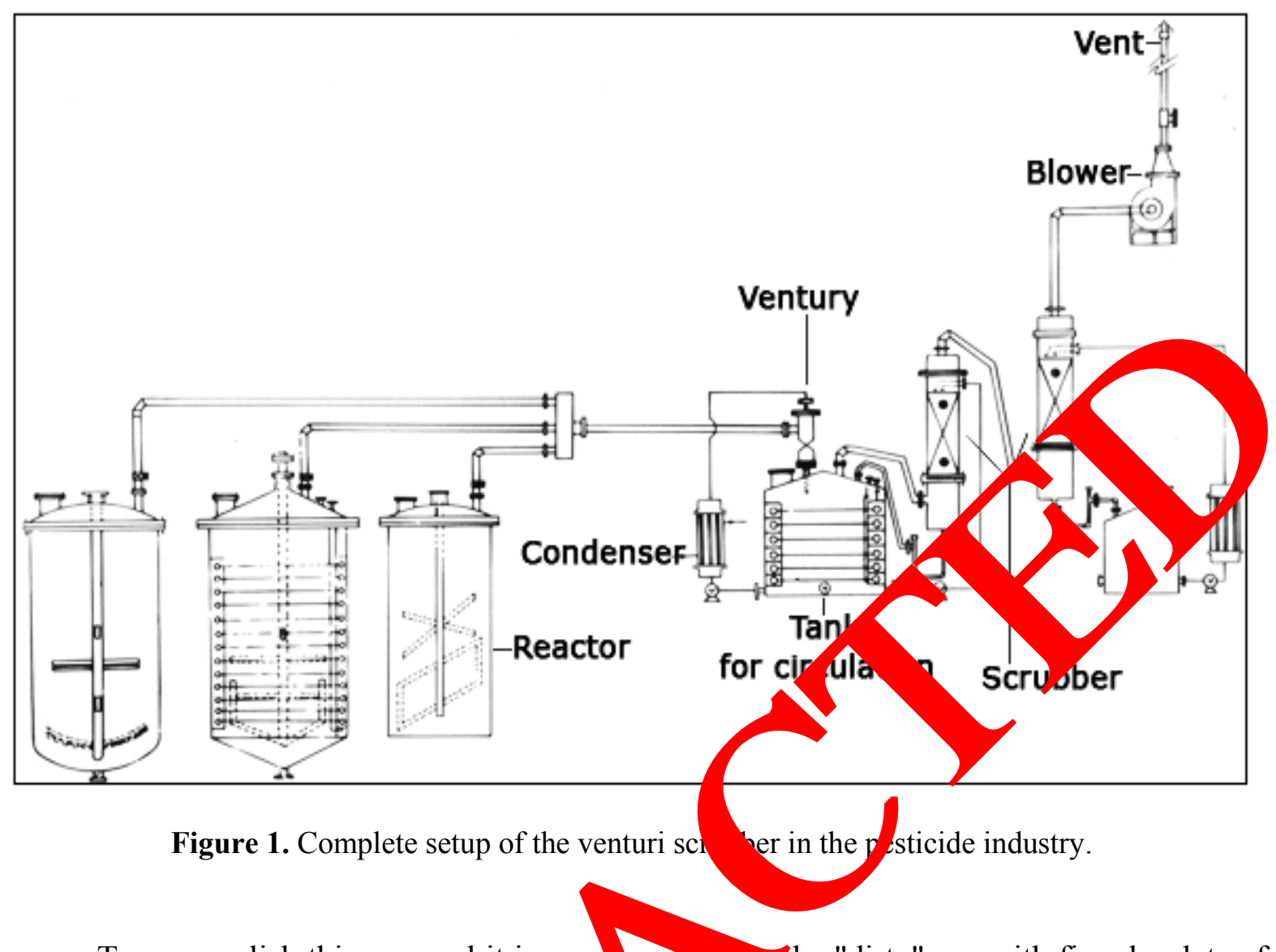

To accomplish this removal it is nece ary whe "dirty" gas with fine droplets of the fluid used to remove them. A Venturi ac omplisnes this by passing the washing fluid through a tapered neck in the $\mathrm{V}$ ittur ozzle il roducing the gas and liquid into the system. The high speed gas breaks th uid $j$ to tiny doplets and mixes them with itself [17]. The fluid picks up the impuritiend ar arger droplets which either fall out of the gas or are collected on imp gement $p_{1}$ or packing. The purified gas leaves the system; the dirty fluid is sent for isp or purifty, for reuse.

\section{3. Emission stream Charay istics}

\subsubsection{Air}

Tumical ga cubi me per su $\left(\mathrm{sm}^{3} / \mathrm{sec}\right)(500$ to 60,000 standard cubic feet per minute $(\mathrm{scfm})$ ). F\% hig or then this range use either multiple venturi scrubbers in parallel or a multiple throat

\section{3. 2. Tè perature}

Inlet gas temperatures are usually in the range of 4 to $370{ }^{\circ} \mathrm{C}(40$ to $700 \mathrm{~F})$.

\section{3. 3. Pollutant Loading}

Waste gas pollutant loadings can range from 1 to 115 grams per standard cubic meter $\left(\mathrm{g} / \mathrm{sm}^{3}\right)(0.1$ to 50 grains per standard cubic foot $(\mathrm{gr} / \mathrm{scf}))$. 


\section{3. 4. Other Considerations}

In situations where waste gas contains both particulates and gases to be controlled, venturi scrubbers are sometimes used as a pretreatment device, removing PM to prevent clogging of a downstream device, such as a packed bed scrubber, which is designed to collect primarily gaseous pollutants.

\section{4. Method}

Generally different models are available for the calculation of Venturi narticle collection efficiency. Johnstone equation, Infinite throat mode, Cut power metb oa, ou ct power theory, Pressure drop.

\section{4. 1. Johnstone' method}

One of the more popular and widely used collection effic a cantions, that originally suggested by Johnstone et al (1954) [10].

$$
\eta=1-e^{-k R\left(K_{p}\right)^{0.5}}
$$

where $\eta$ is the collection efficiency, $K_{p}$ is the inertia impaction parameter (dimensionless), $R$ the liquid-to-gas ratio (gal/1000 acf or gpm/1000 a ( ) and $k$ th correlation coefficient, the value of which depends on the system geometry and atan conditions (typically 0.1-0.2 acf/gal).

The inertial impaction parameter $\left(K_{p}\right)$ is $y$ by Equation 2 , where $d_{p}$ the particle diameter $(\mathrm{ft}), \rho_{p}$ the particle density $\left(\mathrm{lb} / \mathrm{ft}^{3}\right)$, ne thr, at velocity $(\mathrm{ft} / \mathrm{s}), \mu_{G}$ the gas viscosity $(\mathrm{lb} / \mathrm{ft}-\mathrm{s}), d_{d}$ the mean droplet ter (ft) and $C$ the Cunningham correction factor (dimensionless).

The mean droplet diareto air and water in a venturi scrubber is given by the Nukiyama-Tana awa rela ship, shown in Equation 3. The overall collection efficiency of the syste $A$ be calcu using Equation 4, where $M_{d}$ is the weight percent of the particles of a yen a veter.

$$
\begin{gathered}
K_{p}=\frac{C d_{p}^{2} \rho_{p} V_{t}}{9 \mu_{G} d_{d}} \\
d_{d}=\frac{16,400}{V_{t}}+1.45 \times R^{1.5} \\
\eta_{o}=\sum\left(\eta_{d} \times M_{d}\right)
\end{gathered}
$$




\section{4. 2. Pressure drop}

The pressure drop in venturi scrubbers can be calculated by the model developed by Young et. al. (2007) [18] by the following Equation 5:

$$
\Delta P=2 \rho_{L} V_{G}^{2}\left(\frac{Q_{L}}{Q_{G}}\right)\left(1-X^{2}+\sqrt{X^{4}-X^{2}}\right)
$$

where $\Delta P$ the pressure drops $\left(\right.$ dyne $\left./ \mathrm{cm}^{2}\right)$, and $X$ the dimensionless throat leng hich can calculated by Equation 11 (where $l_{t}$ the venturi throat length, in $\mathrm{cm}$ ). The arag coe ient, $D$ for droplets with Reynolds numbers, Re, from 10 to 500 can be obta ed by quatio [9]. The Reynolds number can be calculated using Equation 7 (wb gas c nsity, in $\left.\mathrm{g} / \mathrm{cm}^{3}\right)$.

\section{5. Operating Parameter}

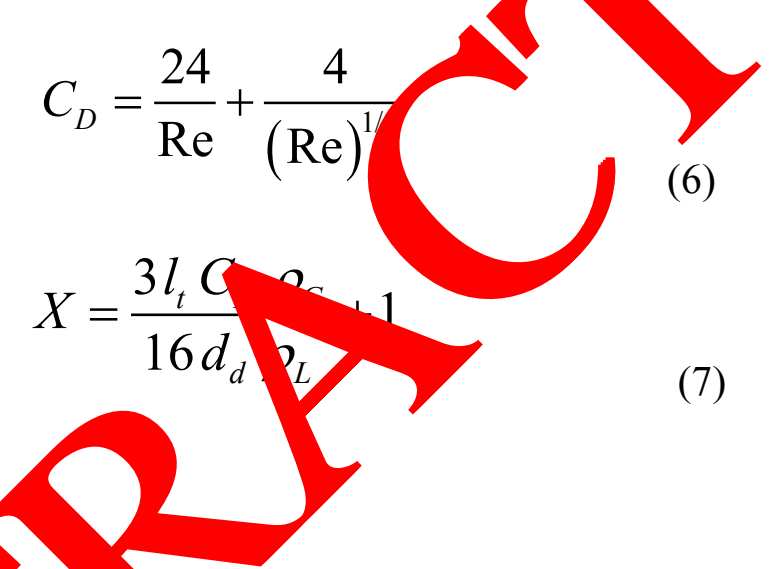

The venturi scrub ro runs w wa different pollutants existing on the plant. When gaseous or the part te pressure rops, liquid to gas ratio, liquid inlet pressure and removal efficiencrat ment in Table 2.

\begin{tabular}{|c|c|c|c|c|c|}
\hline & & $(\Delta \mathbf{P})$ & $\begin{array}{c}\text { Liquid to gas } \\
\text { ration }(\mathrm{L} / \mathrm{G})\end{array}$ & $\begin{array}{c}\text { Liquid inlet } \\
\text { pressure }\left(\mathrm{P}_{\mathrm{L}}\right)\end{array}$ & $\begin{array}{r}\text { Removal } \\
\text { efficiency }\end{array}$ \\
\hline 1 & & $\begin{array}{l}13-250 \mathrm{~cm} \text { of water } \\
(5-100 \text { in of water) }\end{array}$ & $\begin{array}{c}2.7-5.31 / \mathrm{m}^{3} \\
(20-40 \\
\mathrm{gal} / 1,000 \mathrm{ft} 3)\end{array}$ & \multirow{2}{*}{$\begin{array}{l}<7-100 \mathrm{kPa} \\
(<1-15 \mathrm{psig})\end{array}$} & $\begin{array}{l}\text { 30-60\% per } \\
\text { venturi, } \\
\text { depending on } \\
\text { pollutant } \\
\text { solubility }\end{array}$ \\
\hline 2 & Particles & $\begin{array}{l}50-250 \mathrm{~cm} \text { of water } \\
(50-150 \mathrm{~cm} \text { of water } \\
\text { is common) } \\
20-100 \text { in of water } \\
(20-60 \text { in. of water is } \\
\text { common) }\end{array}$ & $\begin{array}{c}0.67-1.34 \\
1 / \mathrm{m}^{3}(5-10 \\
\mathrm{gal} / 1,000 \mathrm{ft} 3)\end{array}$ & & $\begin{array}{l}90-99 \% \text { is } \\
\text { typical }\end{array}$ \\
\hline
\end{tabular}




\section{RESULT AND DISCUSSION}

To determine the efficiency of venturi scrubber it was decided to calculate with Johnstone equation. This type of technology is a part of the group of air pollution controls collectively referred to as wet scrubbers. Venturi devices have also been used for over 100 years to measure fluid flow (Venturi tubes derived their name from Giovanni Battista Venturi, an Italian physicist). About 35 years ago, Johnstone (1949) [10] and other researchers found that they could effectively use the venturi configuration to remove particles from gas streams. The following operating characteristic of venturi scrubber was mantion below.

\section{1. Calculation}

\section{Initial Condition}

1) Mass-media particle size (physical) $d p s=9.0 \mu \mathrm{m}$

2) Geometric standard deviation $\sigma g m=2.5$

3) Particle density $p p=1.9 \mathrm{~g} / \mathrm{cm}^{3}$

4) Gas viscosity $\mu \mathrm{g}=2.0 \times 10^{-4} \mathrm{~g} / \mathrm{cm}$-sec

5) Gas kinematic viscosity vg $=0.2 \mathrm{~cm}^{2} / \mathrm{sec}$

6) Gas density $\mathrm{pg}=1.0 \mathrm{~kg} / \mathrm{m}^{3}$

7) Gas flow rate $\mathrm{QG}=15 \mathrm{~m}^{3} / \mathrm{sec}$

8) Gas velocity in Venturi throat vgt $=90,0 \mathrm{~m} / \mathrm{sg}$

9) Gas temperature (in Vent a11) $=80^{\circ}$

10) Water temperature

11) Liquid density $p^{1}=1000 \mathrm{~kg}$

12) Liquid flow te $\mathrm{Q}_{\mathrm{L}} 0.014 \mathrm{~m} / \mathrm{sec}$

13) Liquid-t -gas ratio L/G $.0009 \mathrm{~L} / \mathrm{m}^{3}$

Step 1. Calc the $C$ ningham slip correction factor. The mass median particle size (physic ${ }^{1-}$ dps is um. secause the particle aerodynamic geometric mean diameter dpg is not nown ve must

\section{Equ}

$\left.\mathbf{d p g}=\mathbf{d}_{\mathbf{H}} \mathbf{C f} \times \mathbf{p p}\right)$ to calculate $d p g$, and calculate the Cunningham

slip correcy on factor $C f$. From Equation:

$$
\begin{aligned}
& \mathbf{C f}=\mathbf{1}+[(6.21 \times \mathbf{1 0 - 4}) \mathbf{T}] / \mathbf{d p s} \\
& \mathrm{Cf}=1+[(6.21 \times 10-4) \mathrm{T}] / \mathrm{dps} \\
& =1+[(6.21 \times 10-4)(273+80] / 9 \\
& =1.024
\end{aligned}
$$




\section{From Equation:}

$\mathrm{dpg}=\mathrm{dps}(\mathrm{Cf} \times \mathrm{pp}) 0.5$

$=9 \mu \mathrm{m}\left(1.024 \times 1.9 \mathrm{~g} / \mathrm{cm}^{3}\right) 0.5$

$=12.6 \mu \mathrm{mA}$

$=12.6 \times 10^{-4} \mathrm{cmA}$

where $\mathrm{A}[=]\left(\mathrm{g} / \mathrm{cm}^{3}\right) 0.5$

Note: If the particle diameter is the aerodynamic geometric mean diameter $d v g$ a in units of $\mu \mathrm{mA}$, this step is not required.

Step 2. Calculate the droplet diameter dd from Equation:

$d_{d}=50 / V_{g t}+91.8(L / G) 1.5$

(Nukiyama and Tanasawa equation):

$\mathrm{d}_{\mathrm{d}}=50 / \mathrm{v}_{\mathrm{gr}}+91.8(\mathrm{~L} / \mathrm{G}) 1.5$

where

$d_{d}=$ droplet diameter, centimeters

$v g r=$ gas velocity in the throat, centimeters p se-orn $G=$ liquid-to-gas ratio, dimensionless

$\mathrm{d}_{\mathrm{d}}=50 /(9000 \mathrm{~cm} / \mathrm{sec})+91.8(09) \quad 5=0.00 \% 80 \mathrm{~cm}$

Step 3. Calculate the in tial param for the mass-media diameter Kpg, By equation

$(\mathrm{K} \mathrm{pg}=(\mathrm{dpg}) 2 / \mathrm{s} /(9 \mu \mathrm{g} \mathrm{da}$

where

$K p g=$ al par ter or mass-median diameter, dimensionless

dpg ar 1 anodynamic geometric mean diameter, centimeters

vgt = gas acity in the throat, centimeters per second

= gas velocity, grams per second centimeter

$\mathrm{d}_{\mathrm{d}}=$ droplet diameter, centimeters

$K \mathrm{pg}=(12.6 \times 104 \mathrm{~cm}) 2(9000 \mathrm{~cm} / \mathrm{sec}) /\left\{\left[9\left(2.0 \times 10^{-4}(\mathrm{~g} / \mathrm{cm}-\mathrm{sec})(0.008 \mathrm{~cm})\right]\right\}=992\right.$

Step 4. Calculate the Reynolds number $N_{R E O}$, using Equation: 
$\mathbf{N}_{\text {REO }}=\mathbf{v}_{\mathrm{gt}} \mathbf{d}_{\mathrm{d}} / \mathbf{v}_{\mathrm{g}}$

Where

$N_{R E O}=$ Reynolds number for the liquid droplet at the throat inlet, dimensionless

$v_{g t}=$ gas velocity in the throat, centimeters per second

$d_{d}=$ droplet diameter, centimeters

$v_{g}=$ gas kinematic viscosity, square centimeters per second

$\mathrm{N}_{\mathrm{REO}}=\mathrm{v}_{\mathrm{gt}} \mathrm{d}_{\mathrm{d}} / \mathrm{v}_{\mathrm{g}}$

$=(9000 \mathrm{~cm} / \mathrm{sec})(0.008 \mathrm{~cm})\left(0.2 \mathrm{~cm}^{2} / \mathrm{sec}\right)$

$=360$

Step 5. Calculate the drag coefficient for the liquid at thro $C D$, using

$C D=0.22+\left(24 / N_{\text {REO }}\right)\left[1+0.15\left(\mathrm{~N}_{\text {REO }}\right)^{0.6}\right]$ where

$C D=$ drag coefficient for the liquid at the thro $t$ ntran e, dimensionless

$N_{R E O}=$ Reynolds number for th liqui lroplet a the throat inlet, dimensionless

$\mathrm{CD}=0.22+\left(24 / \mathrm{N}_{\mathrm{REO}}\right)[1 / 15(\mathrm{Q}) \mathrm{Q}$

$=0.22+(24 / 360)\left[(1 / 0.460)^{0.6}\right]=.628$

Step 6. Now, chlculate the pary Yer characterizing the liquid-to-gas ratio B,

By using :

$\mathbf{B}=/ \mathrm{LG}) /\left(\mathrm{p}_{\mathrm{g}} \mathrm{C}_{\mathrm{D}}\right.$

wher

$B=$ param $y$ characterizing the liquid-to-gas ratio, dimensionless

$L / G=$ liquid-to-gas ratio, dimensionless

$p g=$ gas density, grams per cubic centimeter

$p l=$ liquid density, grams per cubic centimeter

$C D=$ drag coefficient for the liquid at the throat entrance, dimensionless 
$\mathrm{B}=(\mathrm{L} / \mathrm{G}) \mathrm{p}_{1} /\left(\mathrm{p}_{\mathrm{g}} \mathrm{C}_{\mathrm{D}}\right)$

$=(0.0009)\left(1000 \mathrm{~kg} / \mathrm{m}^{3}\right) /\left(1.0 \mathrm{~kg} / \mathrm{m}^{3}\right)(0.628)=1.43$

Step 7. The geometric standard deviation ogm is 2.5 .

The overall penetration $\mathrm{Pt} \mathrm{x}$ is 0.008 .

Step 8. The collection efficiency can be calculated using the equation:

$\boldsymbol{\eta}=\mathbf{1}-\mathbf{P t} *=1-0.008=0.992=99.2 \%$

Step 9. Determine whether the local regulations for particulate emissions required collection efficiency is calculated by using the equation:

$\eta_{\text {required }}=\left(\right.$ dust $_{\text {in }}-$ dust $\left._{\text {out }}\right) /$ dust $_{\text {in }}$

dust $_{\text {in }}=$ dust concentration leading into the Venturi

dust $_{\text {out }}=$ dust concentration leaving the Venturi

$\eta_{\text {required }}=(1100 \mathrm{~kg} / \mathrm{h}-10 \mathrm{~kg} / \mathrm{h}) / 1100 \mathrm{~kg} / \mathrm{hh}=0.991$

$\eta$ required $=99.1 \%$

\section{2. Cost estimation}

The following are cost range ror ventu wet scrubbers of conventional design under typical operating conditions, evelc ed usin EPA cost estimating spread sheets and referenced to the volumetric io rate $f$ the waste stream treated. For purposes of calculating the example cost effectiy aros, pollutant is assumed to be PM at an inlet loading of approximately $7 \mathrm{~g} / \mathrm{sm}^{3} \quad \mathrm{r} / \mathrm{scf}$ ). Th $\mathrm{cts}$ do not include costs for post-treatment or disposal of used solvent or aste 7 . Actua costs can be substantially higher than in the ranges shown for applica no which uire expensive materials, solvents, or treatment methods.

A) Capital t: $\$, 00$ o $\$ 59,000$ per $\mathrm{sm}^{3} / \mathrm{sec}(\$ 3.20$ to $\$ 28$ per scfm)

B) Operating Maintai Cost: $\$ 8,700$ to $\$ 250,000$ per $\mathrm{sm}^{3} / \mathrm{sec}(\$ 4.10$ to $\$ 119$ per scfm), annua 1

C) nnue zed Cos $\$ 9,700$ to $\$ 260,000 \mathrm{per} \mathrm{sm}^{3} / \mathrm{sec}(\$ 4.60$ to $\$ 123$ per scfm), annually D) a $\$ 84$ to $\$ 2,300$ per metric ton ( $\$ 76$ to $\$ 2,100$ per short ton), annuah cost per ton per year of pollutant controlled.

\section{CONCLUSIONS}

Venturi scrubbers are primarily used to control particulate matter (PM), including PM less than or equal to 10 micrometers $(\mu \mathrm{m})$ in aerodynamic diameter (PM), and PM less than or equal 10 to $2.5 \mu \mathrm{m}$ in aerodynamic diameter (PM). Venturi scrubbers PM collection efficiencies range from 70 to greater than 99.9 percent, depending upon the application. Collection efficiencies are generally higher for PM with aerodynamic diameters of 
approximately 0.5 to $5 \mu \mathrm{m}$. Some venturi scrubbers are designed with an adjustable throat to control the velocity of the gas stream and the pressure drop. Increasing the venturi scrubber efficiency requires increasing the pressure drop which, in turn, increases the energy consumption. For PM applications, wet scrubbers generate waste in the form of a slurry or wet sludge. This creates the need for both wastewater treatment and solid waste disposal. Initially, the slurry is treated to separate the solid waste from the water. The treated water can then be reused o discharged. Once the water is removed, the remaining waste will be in the form of a solid or sludge. If the solid waste is inert and nontoxic, it can generally be landfilled. Hazardous wastes will have more stringent procedures for disposal. In somses, the solid waste may have value and can be sold or recycled.

\section{Reference}

[1] Azzopardi B.J. and A.H. Govan (1984), 'The modeling of cur. rubers' filtration and Separation, Vol. 23, pp. 196-200.

[2] Azzopardi B.J., S.F.C.F. Teixeira, A.H. Govan ana C.R. (1991) 'An improved model for pressure drop in Venturi scrubbers', Trumsantions of 'ystitute of Chemical
Engineers, B69, pp. 55-64.

[3] Boll R.H. (1973) 'Particle collection and pres e drop in Y enturi scrubbers' Industrial \& Engineering Chemistry Fundamentals, Vol.

[4] Calvert S., (1970) 'Venturi and oth mizing scrubbers efficiency and pressure drop', AIChE Journal, Vol. 16, pp. 392396

[5] Calvert S., D. Lundgren and Mehta 972) 'Venturi scrubber performance' Journal of Air Pollution Control ssocía on, Vol. \%, pp. 529-532.

[6] Charisiou N.D., G. Joula (2011) 'Software development for the design of contro equipm for particulate pollutants', Proc. Int. Conf. on Environmental ci and Tec, sogy VII, pp. A295-A302.

[7] Goncalves N., D. andez Alonso, M.A. Martins Costa, B.J. Azzopardi and J.R. Coury (2,01) Evaluation the models available for the prediction of pressure drop in Venty rubb J J urnal of Hazardous Materials, Vol. B81, pp. 123-140.

[8] Goncalves S.S., N.A.M. Costa, M.L. Aguiar and J.R. Coury (2004) 'Atomizatin of 11qu in a - Anthony Venturi scrubber. Part II. Droplet dispersion' Journal of Haz: dous Ma erials, Vol. 116, pp. 147-157.

[9] ver C.D. and F.C. Alley (2004) 'Air pollution control: A design approach' Wa 1 Press, Inc.

[10] Johnstone H.F., R.B. Feild and M.C. Tassler (1954) 'Gas absorption and aerosol collection in a Venturi atomizer', Industrial and Engineering Chemistry, Vol. 46, pp. 1601-1608.

[11] Miller R.L., D.M. Jain and M.P. Sharma (1990) 'Modeling Venturi scrubber performance for particulate collection and pressure drop' Chemical Engineering Communications, Vol. 89, pp. 101-112. 
[12] Nasseh S., A. Mohebbi, Z. Jeirani and A. Sarrafi (2006) 'Predicting pressure drop in Venturi scrubbers with artificial neural networks' Journal of Hazardous Materials, Vol. 143, pp. 144-149.

[13] Pulley R.A. (1997) 'Modeling the performance of Venturi scrubbers' Chemical Engineering Journal, Vol. 67, pp. 9-18.

[14] Rudnick S.N., J.L.M. Koehler, K.P. Martin, D. Leith and Cooper D.W. (2006) 'Particle collection efficiency in a Venturi scrubber: comparison of experiments with theory' Environmental Science and Technology, Vol. 20(3), pp. 237-242.

[15] Silva A.M., J.C.F. Teixeira and S.F.C.F Teixeira (2009) 'Experiments Venturi scrubber: Part II. Droplet size' Chemical Engineering and Proc Intensification, Vol 48(1), 424-431.

[16] Theodore L. (2008) 'Air pollution control equipment', John Wil \& \& So Inc.

[17] Wang L.K., W. Lin and Y.T. Hung (2004) 'Catalytic of at Ha book of Environmental Engineering, Volume 1: Air Pollution $C$ ntrol Ens erip s, ed. L.K. Wang, N.C. Pereira and Y.T. Hung, Humana Press Inc Io va, NJ, Us, pp. 369-394.

[18] Yung S.C., H.F. Barbarika and S. Calvert (2007) vessure h in Venturi scrubbers' Journal of the Air Pollution Control Association, Vol. 27, pp. 34 $s 51$.

[19] Yung S.C., S. Calvert and H.F. Barbarika 2008) 'Ven uri Scrubber Performance Model' Environmental Science and Technolog. Vol. 12(4), pp. 456-459.

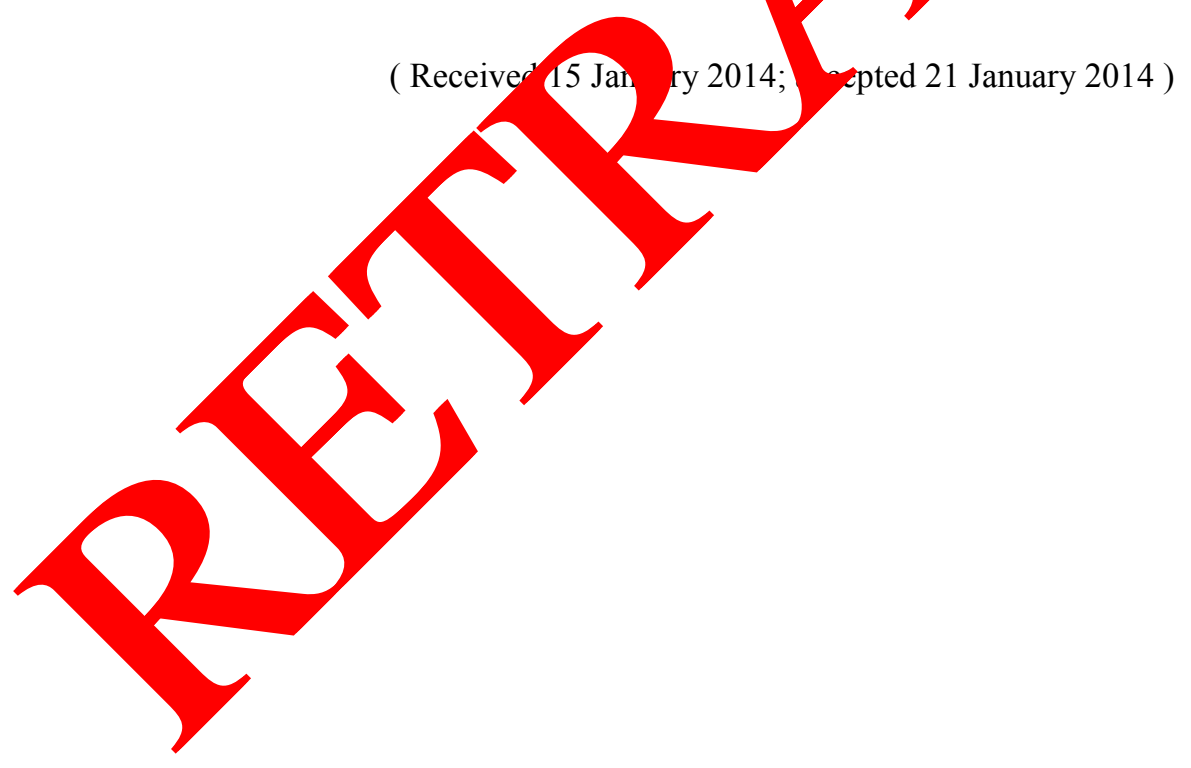

